\title{
Saltwater Intrusion Appraisal of Shallow Aquifer in Burutu Area of the Western Niger Delta with 2D Electrical Resistivity Tomography
}

\section{*11OHWOGHERE- ASUMA, OGHENERO; ${ }^{1}$ CHINYEM, I.FELIX; ${ }^{2}$ ESSI, OGHENEVOVWERO EMMANUEL,}

\author{
${ }^{1}$ Department of Geology, Delta State University Abraka, Nigeria \\ ${ }^{2}$ Department of General studies, School of Marine Technology, Burutu, Delta State
}

\begin{abstract}
The area is faced with endemic groundwater quality problems arising from abandoned shallow and deep boreholes. The abandonment of shallow boreholes is presumed to have been caused by saltwater intrusion from the ocean. The objective of this paper is to examine if saltwater is responsible for groundwater degradation associated with shallow groundwater aquifer. To achieve this, a multi-electrodes ABEM SAS 4000 Terrameter was used in the acquisition of $2 \mathrm{D}$ electrical resistivity tomography data. Inverse models which estimate actual subsurface geologic resistivity was generated from RES2DINV software and subsequently geologic information were construed from them. The interpretation of the various profiles returned resistivity values which contrasted the existence of saltwater in the pore spaces of groundwater aquifer media in the area under investigation. Resistivity images of values ranged from $2.34 \Omega \mathrm{m}$ to $70 \Omega \mathrm{m}$ where interpreted as clays, greater than $70-90 \Omega \mathrm{m}$ as fine sand and $90 \Omega \mathrm{m}$ and above where interpret as medium sand. The evidence revealed by the $2 \mathrm{D}$ electrical resistivity tomography investigation combined with geochemistry of groundwater from literature suggested that abandonment of shallow boreholes are probably not related to saltwater intrusion. The study has established that poor groundwater quality being experienced is not caused by saltwater intrusion rather by iron which cannot be separately distinguished from groundwater by resistivity technique. () JASEM

https://dx.doi.org/10.4314/jasem.v21i2.19
\end{abstract}

Key Word: 2D electrical resistivity tomography, Burutu, Saltwater intrusion, shallow aquifer, western Niger Delta, groundwater quality

The pores spaces which constitute coastal aquifers are filled with groundwater. They are porous and with hydraulic conductivity influenced by the tortuous nature of them. If the groundwater contained in aquifer is fresh, it tends to exhibit a resistant to the flow of introduced current. This is because it is less conductive, and does resist the flow of current through it. These properties describe the nature of freshwater conductivity with respect to an introduced current. If on the other hand, the aquifer contains saltwater, it becomes more conductive and less resistant to an introduced current. This is an important attribute that distinguishes geophysical methods from the other methodologies in groundwater exploration. Consequently it has find major usage in the delineation of freshwater from saltwater in same aquifer and environmental investigation. The electrical resistivity methods including vertical electrical sounding and resistivity profiling, as well as small loop electromagnetic survey are veritable tools for the delineation of saltwater intrusion in coastal aquifers (Hwang et al., 2004; Sherif et al., 2006; and Song, 2006; Atakpo, 2012; Adepelumi et al., 2008;. Oyedele 2001; Amadi et al., 2012; Nwankwoala and Munguye, 2013)

Resistivity profiling can be used to obtain 2D and 3D subsurface geologic information. It also provides both lateral and vertical resolution of resistivity with depth, when compared to the vertical electrical sounding, which provides vertical resolution of resistivity with depth. For this reason, 2D and 3D have found extensive usage in environmental and saltwater intrusion studies.

Similar to most communities of the Niger Delta inhabiting the coastal regions of Nigeria, the study area is faced with endemic water problems. Several shallow and deep boreholes drilled in the area have been abandoned, with few exceptions with good quality groundwater. Thus, making the understanding of groundwater condition complex, as no hydrogeologic explanation on why few boreholes and hand-dug wells having groundwater which are portable and majority are not.

Boreholes drilled into aquifer of $200 \mathrm{~m}$ depth in the study area were abandoned because groundwater from the aquifer is brackish (Oteri, 1998). Considering the depth at which the groundwater is brackish, salinity of the aquifer may have been caused by saline water trapped in sediments during transgression of the sea in geologic past. It may not necessarily through modern sea water intrusion. The reason why boreholes drilled into shallow aquifers are abandoned is poorly understood. The objective of the study is to examine the extent to which saltwater intrusion is responsible for groundwater quality 
degradation in shallow groundwater aquifers of the area.

Geology and Hydrogeology: The sediments beneath Burutu surface comprise of products deposited by fluvial and transition environments. The WarriForcados and the Niger River systems are responsible for depositions of sediments. Ocean tide and waves are responsible for the reworking of sediments deposited at the mouth of Delta. These hydrodynamic processes controlling deposition are probably not different from those which formed the Tertiary Niger Delta Basin in the past.

The river at Burutu is brackish, a characteristics of transitional environment and the extent of brackishness is greatly controlled by seasonal variation, i.e. it more brackish during the dry than wet seasons respectively. The sediments are of Quaternary age and consist of fine grained clay, silts and sands that are unconsolidated. These sediments are said to belong to the Somebreiro-Warri Deltaic Plain deposit which capped the water bearing Benin Formation. The sands which are the aquifers are iron rich and have significant impact on the quality of groundwater. The Somebreiro-Warri Deltaic Plain deposit has thickness less than $200 \mathrm{~m}$ and constitutes the shallow aquifers of the whole of the Niger delta.

The Benin formation is the major water bearing Formation of the entire Niger Delta hydrogeological basin. The lithological composition of which include sands, silts, clays and gravels and occasionally peats. The sand and gravels forms the aquifer in the Formation and are sometimes influenced by heterogeneity. Heterogeneity may have been caused by interaction of clays with sands and termination of sand against clays and vice versa. Though no available pumping data, it is generally assumed from grain sizes and degree of sorting that aquifers possess high hydraulic conductivity and transmisitivity. Therefore very productivity like other aquifers within the Niger delta basin. Most boreholes in the area have been abandoned due to high concentration of iron, especially those whose depth exceeds $40 \mathrm{~m}$ and those shallower than $15 \mathrm{~m}$ are sometimes less affected.
The river systems that drain the area form subcatchments within the Niger Delta basin, especially the western region rivers. The Forcados River at Burutu is noticeably affected by the 6hourly tide. The stage of the river at low tide is $0.4 \mathrm{~m}$ and $1.2 \mathrm{~m}$ during higher tide. The tide has no significant effect on groundwater level (Ohwoghere-Asuma, et al., 2014).

Groundwater aquifer is recharge mainly by infiltration of precipitation and discharge by pumping, evapotranspiration and flow into the River. Groundwater level range from 0.2 to $1.2 \mathrm{~m}$ and is influence by seasonal variations. The direction of groundwater flow is towards the Forcados River (Ohwoghere-Asuma, et al., 2014).The average annual rainfall is above $3000 \mathrm{~mm}$ with frequent rainfall in the wet season.

\section{MATERIALS AND METHODS}

Location of study: Burutu is sandwiched between Latitudes $5^{0} 20^{1} 56.3^{11}, 5^{0} 21^{1} 25.7^{11} \mathrm{~N}$ and Longitudes $5^{0} 30^{1} 10.5^{11} 5^{0} 30^{1} 54.1^{11} \mathrm{E}$ (Fig. 1 ) and located $19 \mathrm{~km}$ from the Gulf of Guinea. It is circumscribed by the River Niger and Focardos River. It is an hour by boat from the city of Warri. Forcados River is marginally brackish at Burutu due to influence of tide, occasioned by the convergence of freshwater from land and marine saline from the sea. The physiographic landforms of mangrove and freshwater swamps characteristics of the Niger Delta are also common in the area.

Acquisition and processing of $2 D$ ERT data: Electrical resistivity tomography was acquired from the field with a multi-electrodes ABEM SAS 4000 Terrameter in a Wenner array configuration. The Wenner array configuration was selected for the study because it is capable of providing both horizontal and vertical resolution of subsurface geology. 64 electrodes spaced on the surface at $5 \mathrm{~m}$ and $2.5 \mathrm{~m}$ respectively were secured into subsurface for current injection and potential difference measurement across two outer and inner electrodes.

In order to have the acquired data in $2 \mathrm{D}$ resistivity models, they were subjected to RES2DINV software, an inversion algorithm of Loke (1999).

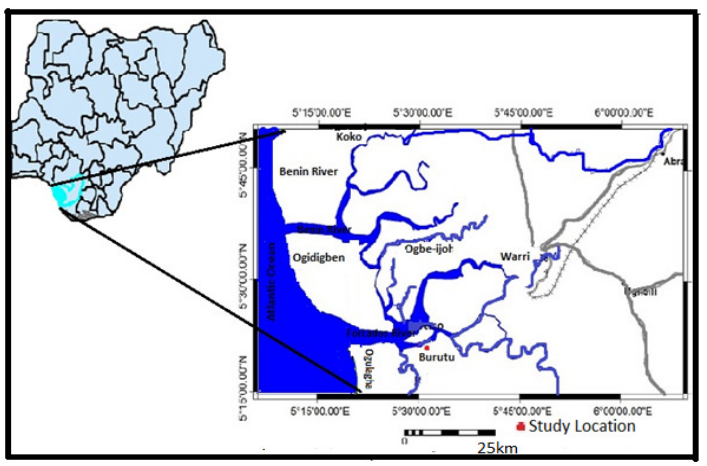

OHWOGHERE- ASUMA, OGHENERO; CHINYEM, I.FELIX; ESSI, OGHENEVOVWERO EMMANUEL, 
Fig.1: Map of the Western Niger Delta showing the Study Area

The outcome of the inversion is a pseduosection was processed further by subjecting them to the rapid least square inversion algorithm proposed by Loke and Baker (1996). This process converts apparent resistivity into true resistivity of the subsurface geologic structure.

The RES2DINV software is capable of performing the inversion routine because it is founded on the smoothness-constrained least square inversion algorithm. The software does this task by dividing the subsurface into rectangular block of grids. The finitedifference method recommended by Dey and Morrison (1979) was applied in obtaining apparent resistivity. A model in which the cell width is half electrode spacing was selected because the acquired data has high resistivity values near the surface than the minimum. Also, in order to obtain more accurate apparent resistivity values, 4 nodes per unit electrode spacing and finest mesh were used. By selecting this options, the spacing between electrodes was reduced from earlier $5 \mathrm{~m}$ to $2.5 \mathrm{~m}$ used in the acquisition of data by the software. The pseudosection contouring method was subsequently used to display apparent resistivity values (Loke, 2000). More details concerning the processing of $2 \mathrm{D}$ data acquisition and interpretation are available in (Kazakis et al., 2016; Loke, 2000; Ohwoghere-Asuma, et.al. 2014a, b, c; Ravindran,et al.,2013; Satriani, 2011 and others).

\section{RESULTS AND DISCUSSION}

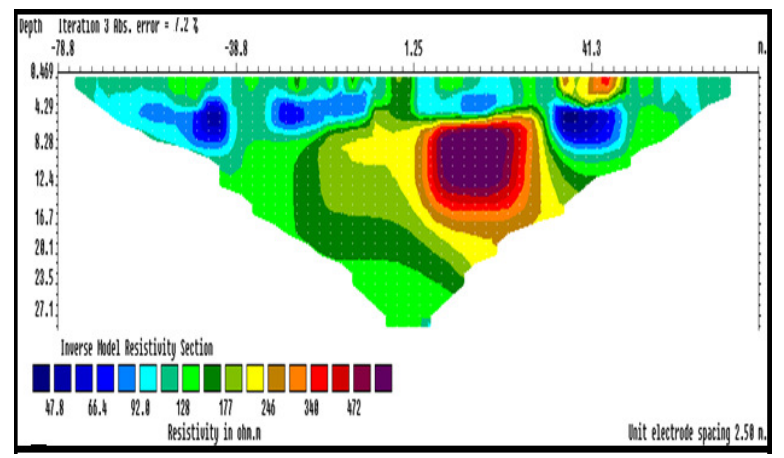

Fig. 2: Showing Inverted model section acquired from Burutu Port Area

Fig. 3 presents the electrical resistivity tomography data obtained from same area perpendicular to Fig. 2. Dominating the uppermost layer of the profile is a high resistivity images, which ranged from 71.7 to $396 \Omega \mathrm{m}$ and sandwiched between the layers are spots of low resistivity images of $2.5 \Omega \mathrm{m}$ and $43 \Omega \mathrm{m}$. The thickness of the layer ranged from surface to about $3 \mathrm{~m}$. Clayey sand and silty sand are interpreted for the high and low resistivity image values respectively. Bearing in mind the shallowness of groundwater aquifer prevalent in this area, the high resistivity images of the topmost layers are probably considered
Fig. 2 illustrates the 2D electrical resistivity tomography (2D ERT) data acquired from the study area. This profile presents resistivity image values quite distinctive in having moderate to relatively high resistivity values. The topmost layer whose depth ranges from 0.469 to $4.29 \mathrm{~m}$ is characterized by a minimum of $47 \Omega \mathrm{m}$ and maximum of $340 \Omega \mathrm{m}$ resistivity image values. Directly underlying it, are successive layers of high resistivity images which ranged from 128 to $340 \Omega \mathrm{m}$. Resistivity values less than $90 \Omega \mathrm{m}$ are probably interpreted as clay and they are discontinuous in lateral extent. Consequently semi-confined aquifer is inferred for this profile, while those whose values are less than $92 \Omega \mathrm{m}$ are presumed to be silty sand and those greater than $92 \Omega \mathrm{m}$ are interpreted as sand. Area of the profile with low resistivity image values is probably regarded as poor quality groundwater, which is attributable to the presence of dissolved ions and iron (Ohwoghere-Asuma, 2014c). The iron content of shallow and deep confined aquifers is typical of the Niger delta water bearing formation, a claim supported by the works of Etu-Efeotor and Akpokodje (1990) and Oteri (1988). The true condition of the groundwater quality in the subsurface along this profile could not be constrained with the electrical resistivity tomography alone, because the groundwater condition is somehow complex and inexplicable; as the distribution of good and poor quality groundwater is somehow not evenly distributed in the area and cannot be determined from resistivity data. 
images characterized by low values are interpreted to range from very poor to fair quality groundwater condition.

Fig. 4 depicts subsurface information in which the top layer is dominated by low resistivity images values that vary between 2.46 and $6.29 \Omega \mathrm{m}$ throughout the profile. This layer forms part of the reclaimed land of the School of Marine Technology, Burutu and it about $2 \mathrm{~m}$ thick. The low resistivity images for this layer may be ascribed to the leaching of dissolved iron fluid which characterized the area (Fig.6). Underlying this, are successive layers of increasing trend of resistivity image values, which ranged between 16.1 and $685 \Omega \mathrm{m}$.

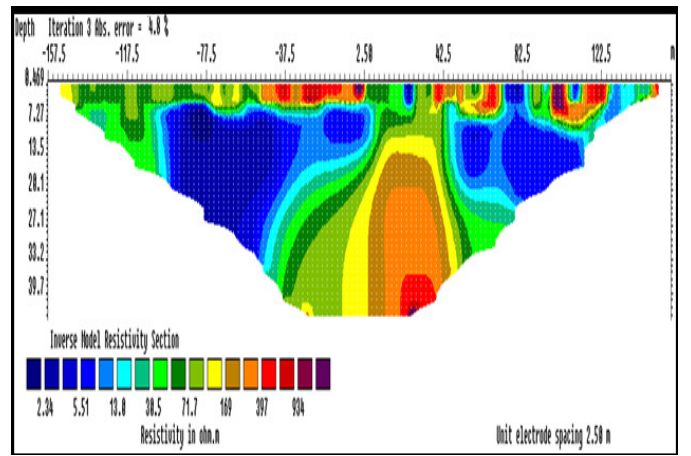

Fig. 3: showing Inverted model section in at NPA quarter road Burutu

Those layers with resistivity images values less than $100 \Omega \mathrm{m}$ were interpreted as clay and silty sand, while those greater were ascribed fine to medium grained sand. The qualities of groundwater that saturate these successive layers are significantly influenced by the concentration of iron dissolved in the aquifers. Consequently the groundwater quality inferred for this area varies from being very poor to fair.

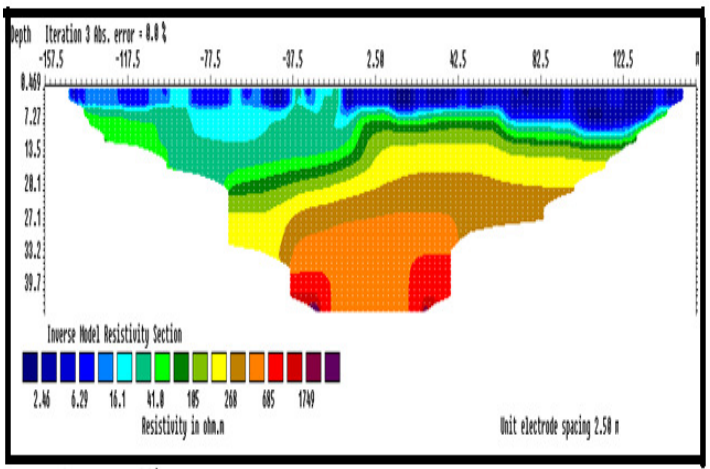

Fig. 4: showing inverted model section for school of Marine Technology Burutu

Fig. 5 is the subsurface formation revealed by the electrical resistivity tomography data acquired from the Burutu township stadium. The layer underlying the ground surface is characterized by variation in resistivity images values, which ranges from 2.46 to $313 \Omega \mathrm{m}$. In this profile spots of low resistivity images are more prevalent than high resistivity images along the top layers. Lithologically clays were inferred for very low resistivity images, those with resistivity values greater than $63 \Omega \mathrm{m}$ and less than 100 were interpreted silty clays, while fine to medium grained sands inferred for those with values above $100 \Omega \mathrm{m}$. Some of those regions related to high resistivity images values may be saturated with groundwater, whose quality is similar to previous profiles determined by the concentration of dissolved iron contained in them.

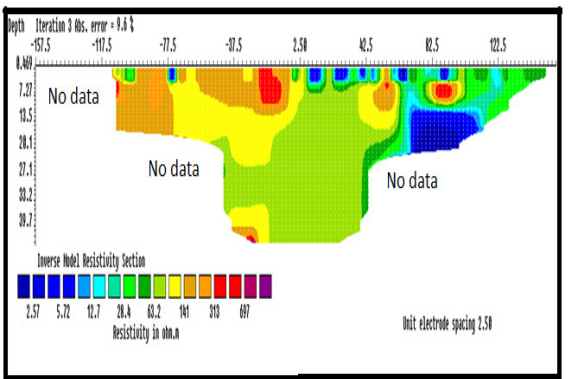

Fig.5: Inverted model section for Burutu township stadium

Generally the resistivity values depicted in this study is somehow related to those acquired by Omamode et al., (2013) but with distinctive interpretation. They adduced low resistivity values to incursion of 


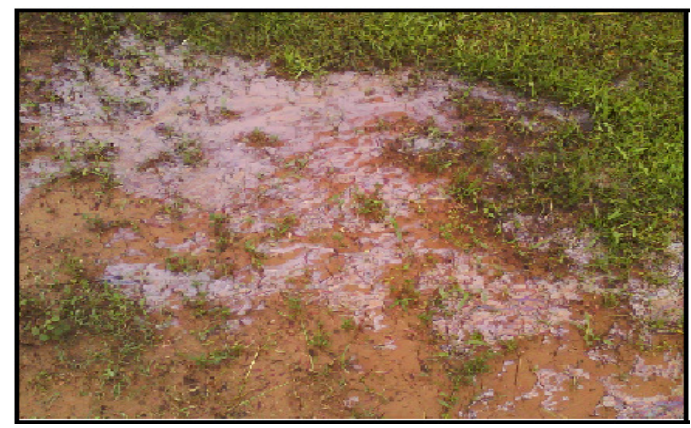

saltwater into shallow aquifer. Later study of same area involving groundwater geochemistry and vertical Fig.6: Pictorial representation of soil impregnated with iron.

electrical sounding by Ohwghere-Asuma, et al., (2014c) showed no evidence of aquifer intruded by saltwater. The depth of occurrence of saltwater suggested by Omamode et al., (2013) is in variant with $200 \mathrm{~m}$ depth of brackish water depicted by Oteri (1988) from log evaluation. Similarly, the work of Uma (1997) has also demonstrated that salinity of creeks has no significant effect on quality of shallow groundwater aquifer in some region of the eastern Niger delta. It is surfeit to say that the study area is similar to those studied by Uma (1997). In our earlier study we observed that groundwater collected from shallow aquifers has three colours; light yellowish, dark and colourless. The problem of groundwater quality in the area, especially shallow aquifer, though needs further investigation, is more of iron and probably organically controlled than saltwater intrusion.

Conclusion: The 2D electrical resistivity tomography data interpreted has shown that degradation of groundwater quality in the study area is not influenced by saltwater intrusion but by other processes which could not be distinguished by electrical resistivity technique used.

Heterogeneities which hinder the flow of groundwater in aquifers are better revealed vertically and laterally by the $2 \mathrm{D}$ electrical resistivity tomography.

\section{REFERENCES}

Adepelumi, A. A (2008). Delineation of Saltwater intrusion into the freshwater aquifer of Lekki Peninsula, Lagos, Nigeria. The 3rd International Conference on Water Resources and Arid Environments (2008) and the 1st Arab Water Forum

Amadi, A.N; Nwankwoala, H.O; Olasehinde, P.O; Okoye, N.O; Okunlola, Y.B. Alkali, I.A . (2012). Investigation of Aquifer Quality in Bonny Island, Eastern Niger Delta Using Geophysical and Geochemical Techniques. J. of
Emerging Trends in Engineering and Applied Sciences (JETEAS). 3(1):183 - 187.

Atakpo, E.O (2013). Geoelectric Investigation of Deghele Community in Warri SouthWest L.G.A, Delta State, Nigeria. IOSR J. of Applied Physics. 3(1): 46-50.

Dey, A; Morrison, H.F (1979). Resistivity Modelling for Arbitrary Shape Two-Dimensional Structures. Geophy. Prospect. 37: 106-136.

Etu-Efeotor, J.O; Akpokodje, E.G (1990). Aquifer Systems of the Niger Delta. J. Min. Geol. 26(2): 279-284.

Hwang, S; Shin, J; Park, I; Lee, S (2004). Assessment of Seawater Intrusion Using Geophysical Well Logging and Electrical Soundings in a Coastal Aquifer, Youngkwang-Gun, Korea. Expl. Geophys. 35. 99-104.

Kazakis, N; Pavlou, A; Vargemezis, G; Voudouris, K.S; Soulios, G; Pliakas, F; Tsokas, G ( 2016) Seawater Intrusion Mapping Using Electrical Resistivity Tomography and Hydrochemical Data.: An Application in the Coastal Area of Eeastern Thermaikos Gulf, Greece. Science of the Total Environment. 543: 373-387.

Loke, M.H; Barker, R.D (1996). Rapid Least-Squares Inversion of Apparent Resistivity Pseudosections by a Quasi-Newton Method, Geophysical Prospecting. 44: 131-15.

Loke, M.H (1999). Electrical Imaging Surveys for Environmental and Engineering Studies, User Manual for RES2DINV Electronic Version Available from http://www.geometrics.com.

Loke, M.H (2000). Electrical Imaging Surveys for Environment and Engineering Sstudies. A Practical Guide to 2D and 3D Survey, Electrical Version available from http://www.geometrics.com

Nwankwoala, H.O; Omunguye, M.L; (2013). Geophysical Investigation for Groundwater in Borokiri and Eastern-Bye Pass Areas of Port Harcourt, Nigeria.Pacific J. of Science and Technology. 14(1):524-535.

Ohwoghere-Asuma, O., Akpoborie, I.A., Akpokodje E.G., (2014a). Investigation of saltwater intrusion in Warri-Effurun shallow groundwater aquifer from $2 \mathrm{D}$ electrical resistivity imaging and hydraulic gradient data. New York science Journal; 7(12): 20-29.

Ohwoghere-Asuma, O., Aweto, K.E., Akpoborie, I.A. (2014c). Investigations of groundwater quality 
and Evolution in an Estuary Environment: A case study of Burutu Island, western Niger Delta, Nigeria. Journal of Environmental Hydrology 22(5); 1-14.

Ohwoghere-Asuma, O., Chinyem, F.I., Nwankwoala, H.O (2014b). 2D Resistivity Electrical Imaging of Unsaturated and Saturated Zones for crude oil spillage at Agbarha in Ughelli area of Delta State, Nigeria; New York science Journal; 7(12): 30-35

Omamode S. M., Ohwona C. O., Ojo K. O. (2014). Groundwater Deductions from Geoelectric Survey in Burutu Island, Delta State, Nigeria. Research Journal of Environmental and Earth Sciences 6(4): 182-188, 2014.

Oteri, A.U. (1988). Electric Log Interpretation for the evaluation of salt water intrusion in the eastern Niger Delta. Hydrol. Sciences Journ. 33 (1/2), 19-30.

Ravindran, A. A., Ramanujam, N., Sudarsan, R, (2013). Delineation of Saltwater and Freshwater Interphase in Beach Groundwater Study Using 2D ERI
Satriani, A. Loperte, A., Proto, M (2011), Electrical Resistivity Tomography for coastal salt water intrusion characterization along the Ionian Coast of Basilicata Region (southern Italy). International Water Technology Journal, I (1); 83-90

Sherif, M., El Mahmoudi, A., Garamoon, H., Kacimov, A., Akram,S., Ebraheem, A. and Shetty, A., (2006). Geoelectrical and hydrogeochemical studies for delineating seawater intrusion in the outlet of Wadi Ham, UAE. Environmental Geology, 49, 536-551.

Song, S.H. (2006). Spatial analysis of small-loop electromagnetic survey data in a seawater intrusion region. Exploration Geophysics, 37, 114-120.

Technique in the Northern Sector of the Gulf of Mannar Coast, Tamilnadu. Water 5; 1-11.

Uma, K. O (1997). Salinization of shallow sandy coastal aquifers; a case study from parts of the Niger Delta region of Nigeria, Hydrology of the Humid Tropic Environment; Proceeding of International symposium Held at Kingston, Jamaica, IAH Pub. No. 247, 1997. 